\title{
TRADISI NISAN MENHIR PADA MAKAM KUNO RAJA-RAJA DI WILAYAH KERAJAAN HITU
}

\author{
The Tradition of Menhir Tomb in the Ancient Tomb \\ of Kings in the Kingdom of Hitu
}

\author{
Wuri Handoko \\ Balai Arkeologi Ambon \\ Jln. Namalatu-Latuhalat 97118 \\ Email :wuri_balarambon@yahoo.com
}

Naskah diterima: 08-01-2014; direvisi: 25-04-2014; disetujui: 09-05-2014

\begin{abstract}
The Tradition of menhir headstone is an ancient tomb tradition by using a grave form of menhir stones. This tradition is a form of the tradition continues, as menhirs are upright stones as a sign of respect for ancestors in the megalithic tradition. This study aims to explain the tradition of Islamic tombs of the kings in the Kingdom Hitu since the beginning of the Islamic conversion and development period and how the megalithic tradition in the form of Islamic tomb when people have to convert Islam as a religion. This study was conducted using a survey to gather information and describe the forms of ancient Islamic tomb kings Hitu in central Moluccas. The results show though Islam has been adopted as the royal religion or public religion, characterized mengkonveris leaders of Islam, but confidence in the ancestor as local pre-Islamic religious understanding develops, still adhered to and maintained. Tomb tombstone shape using menhir, is one form of continuity megalithic tradition in the episode acceptance of Islam by the public since the beginning of its development, until the establishment of the Islamic government to appear in the king institutions Hitu region.
\end{abstract}

Keywords: Tomb, Tombstone, Menhir, Islam, Hitu.

\begin{abstract}
Abstrak
Tradisi nisan menhir adalah, tradisi makam kuno dengan menggunakan tanda kubur berupa batu menhir. Tradisi ini merupakan bentuk tradisi berlanjut, karena menhir adalah batu tegak sebagai tanda penghormatan terhadap leluhur dalam tradisi megalitik. Penelitian ini bertujuan menjelaskan tradisi makam Islam raja-raja di Kerajaan Hitu sejak awal konversi Islam dan masa perkembangannya serta bagaimana tradisi megalitik pada bentuk makam Islam ketika masyarakat sudah mengkonversi Islam sebagai agamanya. Penelitian ini dilakukan dengan metode survey untuk mengumpulkan informasi dan mendeskripsikan bentuk-bentuk makam kuno Islam raja-raja Hitu di Maluku tengah. Hasil penelitian menunjukkan meskipun Islam telah dianut sebagai agama kerajaan atau agama publik, ditandai para pemimpinnya mengkonveris agama Islam, namun kepercayaan terhadap leluhur sebagai paham religi lokal sebelum Islam berkembang, masih tetap dianut dan dipertahankan. Bentuk makam dengan menggunakan nisan menhir, merupakan salah satu bentuk kontinuitas tradisi megalitik dalam episode penerimaan Islam oleh masyarakat sejak awal perkembangannya, hingga masa terbentuknya pemerintahan Islam dengan muncul lembaga raja di wilayah Hitu.
\end{abstract}

Kata Kunci : Makam, Nisan, Menhir, Islam, Hitu 


\section{PENDAHULUAN}

Membahas masalah konversi Islam, masyarakat di wilayah Maluku, termasuk dalam hal ini di wilayah kekuasaan Kerajaan Hitu, tidak pernah bisa lepas dari pembahasan soal isu-isu menyangkut masalah transisi dan transformasi, dari masyarakat yang menganut religi lokal (animisme dan dinamisme) dengan kontak awal pengenalan religi Islam. Dalam konteks ini, pengenalan terhadap Islam, memungkinkan Islam dengan budaya dan tradisi pra islam saling terintegrasi. D wilayah Maluku, masyarakat tradisional di wilayah ini adalah masyarakat yang sangat kuat mempertahankan tradisi, sehingga ketika Islam masuk, anasir-anasir budaya lokal tidak bisa dihilangkan begitu saja Bentuk-bentuk akomodatif Islam dengan budaya lokal, dalam berbagai aspek dapa ditinjau dari karakteristik budaya material yang dihasilkan baik itu berbentuk bangunan atau fitur maupun data artefaktual. Salah satu data arkeologi yang dapat menggambarkan bagaimana keberagamaan Islam masyarakat lokal adalah wujud fisik makam-makam kuno.

Pembahasan mengenai ragan tinggalan arkeologi Islam, diantaranya makammakam kuno, merupakan perbincangan yang selalu mewarnai setiap pembahasan tentang karakter dan dinamika Islam di wilayah Nusatara. Makam Kuno sebagai salah satu fitur Islam, sejauh ini selalu dihubungkan dengan bagaimana model keberlanjutan tradisi ketika Islam menjadi agama yang dikonversi masyarakat secara luas. Hal in karena makam kuno, sebagai artefak dan fitur Islam, dapat memberikan gambaran bagaimana perkembangan akulturasi antar Islam dan elemen-elemen budaya lokal yang bertahan. Malinowsky (1945) mengatakan, analisis suatu proses akulturasi sebaiknya dimulai secermat mungkin dalam wujud suatu kebudayaan itu datang dan mempengaruhi suatu kebudayaan penerima (Ambary, 2008:195). Selanjutnya menambahkan itu Ambary mengatakan, bahwa dalam aspek budaya material, refleksi sosialisasi Islam Nsuantara, banyak dipengaruhi antara lain $s a t u$, kenyataan historis serta realitas sosial identifikasi terhadap dasar legitimasi cultural untuk diterimanya Islam dan ketiga : proses serta strategi yang dikembangkan secara loka dalam sosialisasi Islam (ibid). Penjelasan Ambary tersebut susungguhnya menjelaskan bahwa Islam berkembang karena menerapkan strategi sosialisasi yang mengadaptasi budaya lokal, dimana Islam disosialisasikan, di wilayah setempat, hal ini karena sebelum Islam berkembang, masyarakat telah mengenal sistem kepercayaan atau religi yang berkembang sebelum Islam.

$$
\text { Untuk melihat bagaimana }
$$

sosialisasi Islam, bagaimana Islam dianu dan perkembangannya, salah satu data arkeologi yang digunakan adalah makam kuno Islam. Makam kuno, dapat dianggap sebagai data arkeologi Islam yang dapa menjelaskan bagaimana karakter Islam dikonversi masyarakat dan bagaimana perkembangannya. Hal ini karena pada wujud fisik makam, dapat menjelaskan tentang konsep Islam dalam hal memakamkan orang yang mati. Dalam konsepsi ada masyarakat di Maluku, makam kuno Islam disebut makam keramat, karena biasanya yang dimakamkan adalah tokoh-tokoh besar dalam Islam baik itu penyebar Islam, biasanya dianggap sebagai wali maupun penguasa ataupun pemimpin Islam pada zamannya, Sultan, Raja, Imam dan tokoh besar lainnya yang disakralkan dan dhormati. Jadi, makam Islam disebut keramat hanya berlaku pada makam wali atau penguasa wilayah Islam. Ambary (1998), mengatakan soal pengkeramatan makam, tampaknya ha itu juga merupakan tradisi sebagian besar masyarakat Muslim di wilayah Nusantara (Ambary, 1998: 67).

Makam dianggap suci dan keramat, bahkan kadang secara keliru dijadikan sebagai tempat meminta suatu keberkahan Islam tentu saja tidak mengenal upacaraupacara perkabungan atau peringatan kematian di luar tata cara baku dalam perawatan jenazah sampai pemakaman.
Namun di Indonesia dikenal adanya peringatan kematian pada hari-hari ketiga, ketujuh, empat puluh, seratus dan seribu hari yang semata-mata berdasar adat pra Islam. yang semata-mata berdasar adat pra Islam. maupun berbagai bentuk tradisi penguburan, termasuk dalam soal pembangunan makam yang terjadi di Indonesia, yang sebagian jelas bertentangan dengan hadist, tentu harus dilihat sebagai kenyataan lain, kendati tetap bukan dalam konteks pengingkaran akidah Islam. Hal tersebut tepatnya lebih pada tingkatan mu'amalat, yaitu halhal teknis yang terus berlanjut dari akar tradisi pra-Islam,khususnya mengenai permanensi etnografis dalam penghormatan permanensi etnografis dalam penghormatan mengakui kematian, karenanya ia kerap kali disamarkan dengan atau tafsiran sebagai "kembali ke alam dewa", 'hilang', 'sirna' dan sebagainya. Oleh karena itu makam tidak dianggap sebagai kubur dalam pengertian Islam, melainkan sebagai tempat "tidur panjang'(pasarean) "astana”, atau tempat ketenangan (kasunyatan). Selain itu, peninggalan makam-makam Islam awal, seringkali berkonotasi jenis okupasi komunitas muslim, yang sekaligus menunjukkan keberagaman pertanggalan bukti kehadiran Islam di Nusantara (Ambary, 1998:43).

Demikian pula di wilayah-wilayah penelitian arkeologi Islam selama ini di Maluku. Sebagian besar keramat adalah, makam-makam tokoh. Meskipun demikian, dari wujud fisik yang ada, tampaknya makam sangat sederhana, sekalipun makam tokoh seperti raja atau pemimpin negeri. Di wilayah kerajaan Hitu, yang dianggap sebagai pusat kekuasaan Islam di wilayah Kepulauan Maluku bagian selatan, bahkan perannya dalam sosialissasi Islam disejajarkan dengan kesultanan Ternate, namun bentuk-bentuk makamnya sangat sederhana, pada umumnya dengan jirat terbuka, dan nisan berupa nisan menhir. Penelitian ini, dimaksudkan untuk melihat tradisi makam raja-raja di wilayah Kerajaan Hitu, untuk melihat perkembangan
Islam itu sendiri.

Pembahasan menyangkut identitas Islam, walaupun jarang terangkat, namun membuktikan bahwa praktek penganutan Islam, baik pada awal agenda Islamisasi maupun perkembangan kontempore menunjukkan bahwa Islam tidak sematamata unsur yang tunggal, namun di dalamnya terdapat anasir-anasir luar baik budaya lokal maupun pengaruh budaya luar lainnya. Data makam kuno, dianggap dapat menjelaskan dan memperlihatkan dengan jelas bagaimana Islamisasi dan konvers Islam berlangsung. Namun beberapa data menyangkut perilaku dan tradisi Islam kontemporer dapat menjadi petunjuk tentang proses keberagamaan Islam masyarakat penganutnya. Bukti-bukti arkeologi, maupun perkembangan kontemporer masyaraka saat kini, menunjukkan gambaran tentang identitas Islam atau bagaimana keberagamaan Islam berlangsung.

Berdasarkan hal itu, maka rumusan masalah dalam penelitian ini adalah :

1. Bagaimana tradisi makam kuno pemimpinpemimpin Islam di wilayah Kerajaan Hitu?

2. Bagaimana gambaran tentang konversi Islam, hubungannya dengan dinamika budaya lokal masyarakat setempat?

Permasalahan ini merupakan diskursi yang sebenarnya sangat umum di wilayah-wilayah penelitian arkeologi Islam di Nusantara, mengingat pada umumnya, persentuhan Islam dengan budaya loka yang hadir jauh sebelum Islam sangat kenta dan saling melekat, mengingat tradisi pra Islam di banyak tempat terus bertahan, $\mathrm{d}$ samping Islam memang sangat akomodati dengan paham-paham lokal. Namun kajian in dibatasi untuk melihat karakteristik makam kuno untuk melihat bagaimana relasi Islam dengan budaya lokal yang masih bertahan.

Insoll (2004) menjelaskan bahwa pembahasan identitas dalam arkeologi Islam sering diperlakukan seolah-olah Islam adalah kategori monolitik, namu pada kenyataannya terdiri dari berbagai 
identitas variabel, seperti yang berputar di sekitar sektarian, etnis atau afiliasi gender misalnya. Idealnya, Islam harus terstruktu dan secara ideologis dengan tegas tidak berhubungan dengan identitas etnis tetap dalam kenyataannya didalamnya terdapa unsur atau divisi berdasarkan kelas, kasta, etnis, pendudukan dan sejenisnya (Barth 1969 38; Insoll, 2004: 112). Barangkali pemikiran ini sama halnya seperti yang diungkapkan Ambary, bahwa Islam pada beberapa aspek berkesinambungan dengan anasir buday dari etnis tertentu (permanensi etnologis) yang telah muncul jauh sebelum Islam itu sendiri diterima masyarakat (Ambary 1991, 1998). Bentuk permanensi emogis 1998). Bentuk permanensi enologis yan dapat segera diamati adalah adanya tradisi
nisan makam dengan menggunakan batu berbentuk menhir. Menhir berarti batu tegak, yaitu sebuah batu panjang yang didirkan tegak, berfungsi sebagai batu peringatan dalam hubungannya dengan pemujaan arwah leluhur (Soejono, 1993:321). Sementara itu Haris Sukendar mengatakan, umumnya menhir digunakan dalam kurun waktu yang panjang, maka tidaklah mengherankan jika terdapat perkembangan pada bentuk-bentuk menhir dan fungsinya. Menhir merupakan tinggalan tradisi megalitik yang sangat banyak ditemukan di berbagai situs dan berbagai masa setelah periode Neolitik, yang terus berkembang hingga masa pengaruh Hindu, Islam bahkan hingga masa sekarang (Sukendar, 1983:93). Menhir merupaka tinggalan tradisi megalitik yang banyak ditemukan di setiap wilayah di Nusantara Menhir atau batu tegak, menurut Sukendar (1983) secara umum mempunyai tiga fungs : yaitu batu tegak yang berfungsi dalam upacara penguburan, upacara pemujaan dan batu tegak yang tidak berfungsi religius (Sukendar, 1983: 100).

Fungsi menhir, sebagai pertanda adanya penguburan dapat dilihat di berbagai daerah. Wiyana (2008) mengatakan pemberian tanda (misalnya tanda dari kayu atau batu) pada penguburan Islam merupakan sala satu sunnah, sebagaimana hadis diriwayatan
Ahmad dan Muslim,"disunahkan memberi gan batu atau tanda lain pada bagian kepala". Pemberian tanda berupa menhir pada masa prasejarah dan nisan pada masa Islam, secara prinsip mempunyai kesamaan, yaitu sebagai tanda adanya penguburan. Adanya kesamaan in menimbulkan pemanfaatan fungsi, terutama dari fungsi atau bentuk menhir yang berfungsi sebagai tanda kubur pada masa Islam (Wiyana, 2008:311).

Makam adalah salah satu hasil budaya manusia yang berkembang pada masa Islam. Sebagai hasil budaya, dalam proses pembuatan makam tentunya harus memperhatikan beberapa faktor sebelum makam dibentuk Diantara beberapa faktor tersebut antara lain kaidah-kaidah normatif Islam tentang pemakaman, bahan baku, dll. Bahan baku makam sebagai salah satu faktor pembuatan makam tidak dapat dipisahkan dengan faktor lingkungan keberadaan makam. Tingginya ketergantungan masyarakat pada sumberdaya yang dihasilkan oleh alam, termasuk dalam hal teknologi dan bahan pembuat makam, menunjukkan tingkat adaptasi budaya juga masih sangat tergantung pada alam. Adaptas secara umum sering diartikan sebagai proses yang menghubungkan sistem budaya dengan lingkungannya (Kaplan dan Manners, 1999: 112). Dalam arti lebih sempit adaptasi dapa ditafsirkan sebagai usaha manusia untuk menyesuaikan diri dengan lingkungannya. Faktor lingkungan berperan penting dalam mengubah perilaku manusia. Salah satu bentuk penyesuaian manusia terhadap lingkungannya adalah usaha manusia untuk mencari bahan baku dalam membuat hasi budayanya. Sebagai hasil budaya, dalam proses pembuatan makam tentunya harus memperhatikan beberapa faktor sebelum makam dibentuk. Diantara beberapa faktor tersebut antara lain kaidah-kaidah normatif Islam tentang pemakaman, bahan baku, dll. Bahan baku makam sebagai salah satu faktor pembuatan makam tidak dapat dipisahkan dengan faktor lingkungan keberadaan makam (Wiyana, 2005:3).
Bahan baku pembuatan makam (nisan) lebih cenderung memanfaatkan bahan baku yang tersedia di sekitarnya yang lebih dekat, dibanding dengan memanfaatkan bahan lain yang lebih jauh, meskipun mempunyai tingkat keawetan yang lebih tinggi. Makam di daerah pantai akan lebih banyak memanfaatkan bahan baku yang banyak terdapat di pantai, misalnya batu karang. Makam di dataran tinggi akan lebih banyak memanfaatkan batu andesit atau batu kali yang banyak tersedia di daerah tersebut. Sedangkan makam di dataran rendah dan banyak terdapat pohon kayu, akan memanfaatkan kayu sebagai bahan baku. Makam dapat juga dikaji dari bahan baku penyusunnya. Berdasarkan data makam di Indonesia, bahan makam (terutama nisan) dapat dibagi menjadi: bahan kayu (jati, unglen, besi, dll), batu (andesit, kapur, pasir, granit, marmer, dll), dan logam (kuningan, perunggu, dll) (Ambary, 1998: 18).

Kartodirjo (1975:200) menjelaskan, menhir dalam alam kepercayaan masyarakat megalithik berfungsi sebagai medium penghormatan, menjadi tahta kedatangan roh, sekaligus lambang dari orang-orang yang diperingati. Dengan demikian kontinuitas tradisi megalitik yakni penggunaan menhir sebagai nisan kubur, menandai karakteistik Islam yang sangat akomodatif terhadap paham-paham lokal yang merupakan bentuk kepercayaan terhadap leluhur yang diwarisi sejak zaman megalitik dan terus bertahan hingga persentuhannya dengan Islam.

\section{METODE}

Metode penelitian ini dilakukan melalui survey untuk mengumpulkan dan mendeskripsikan data arkeologi berwujud makamkuno.Deskripsibentuk makamterutama nisan, dilakukan untuk mengidentifikasi karakteristik nisan yang berguna untuk membangun interpretasi. Pengumpulan data dilakukan di wilayah-wilayah yang pada masa lampau bagian dari wilayah kekuasaan atau pemerintahan kerajaan Hitu. Deskripsi dilakukan meliputi deskripsi metrik, bentuk dan bahan penyusun makam. Identifikasi dan analisis berdasarkan kecenderungan umum bentuk nisan. Interpretasi dilakukan dengan mengintegrasikan bentuk-bentuk nisan dengan hasil wawancara dan studi pustaka yang berkaitan dengan sejarah Islamisas dan tradisi-tradisi lokal yang berkembang di wilayah penelitian

\section{HASIL DAN PEMBAHASAN}

Unsur-Unsur Tradisi Megalitik Pada Makam Kuno Islam Raja-Raja Hitu

Temuan arkeologgi Islam yang utama

adalah adanya kompleks makam kuno raja-raj Islam Kerajaan Hitu. Dalam tradisi megalitik, makam bisanya diwujudkan dalam bentuknya yang sederhana. Pada makam, bisanya hanya terdiri dari jirat susunan batu dengan nisan baik nisan kepala maupun nisan kak berupa nisan batu berbentuk menhir. Dalan tradisi megalitik, anasir megalitik terlihat juga misalnya adanya perlakuan khusus masyarakat sekitar maupun masyarakat luar kota terhadap keramat-keramat tersebut. Pada dasarnya perlakuan yang dipraktikan adalah ziarah, yang di dalamnya mengandung harapan-harapan tertentu.

Menurut kajian Hasan Muarif Ambary (1991) perlakuan tersebut muncul karen adanya emosi keyakinan dan kepercayaan sehingga objek yang sebenarnya profan, di mata masyarakat itu menjadi sakral. Kehidupan religi ini mendapat suatu reduks dengan masa pra-Islam. Makam atau kubu para tokoh terkenal (raja, wali, pemuka agama) mendapat perlakuan tertentu dari sebagian masyarakat. Makam seperti berada dalam konteks sistem perilaku, yaitu sebagai objek peziarahan yang secara keliru dijadikan medi meminta sesuatu. Pada hari-hari tertentu masyarakat mengadakan upacara dengan membersihkan makam, menaburi bunga, memberi wewangian, serta perlengkapan upacara lainnya. Pada saat ini terjalin kontak langsung dengan sang tokoh. Masyarakat yang datang, meminta atau mohon ijin sesuatu. Mereka memohon kepada Allah dengan perantara sesuatu (Sudewo, 1990: 118-121). Ambary (1998:43) mengatakan soal 
pengkeramatan makam, tampaknya hal itu juga merupakan tradisi sebagian besar masyarakat Muslim di wilayah Nusantara, terutama di Jawa. Makam dianggap suci dan keramat bahkan kadang secara keliru dijadikan sebaga tempat meminta suatu keberkahan. Islan tentu saja tidak mengenal upacara-upacara perkabungan atau peringatan kematian luar tata cara baku dalam perawatan jenazah sampai pemakaman. Namun di Indonesia dikenal adanya peringatan kematian pada hari-hari ketiga, ketujuh, empat puluh, seratus dan seribu hari yang semata-mata berdasar adat pra Islam. Aktivitas ziarah kubur merupakan bentuk perkembangan dari budaya megalitik yang berkembang pada masa prasejarah. Berdasarkan informasi penduduk setiap tahun, yakni setiap 7 Syawal, masyararakat selalu datang berziarah ke kompleks makam raja-raja Hitu.

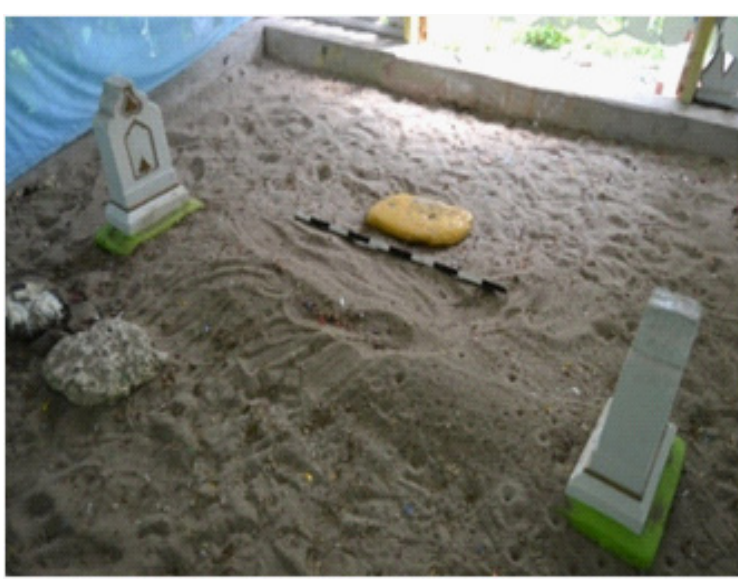

Gambar 1. Makam Latusitania (Raja Hitu I)
(Sumber : Dokumen Balar Ambon, 2012)

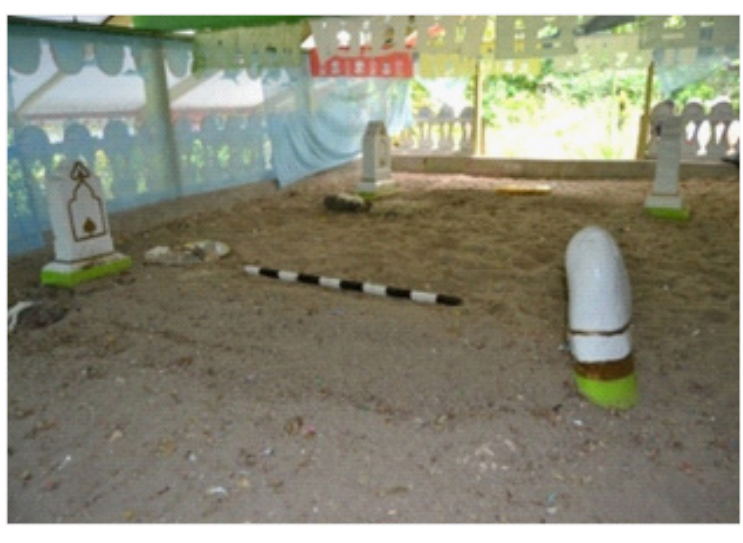

Gambar 2. Makam Istri Latusitania (Raja Hitu I) (Sumber : Dokumen Balar Ambon, 2012)
Di wilayah Hitu, terdapat beberapa makam kuno Islam raja-raja Hitu. Makam pertama adalah Makam Raja Maulana Syeh Abubakar Nasidik (Latusitania, Raja Hitu Pertama). Makam ini berada pada sebuah dataran tinggi terletak sejajar dengan ketinggian masjid tua di negeri lama Amahitu. Keletakan makam berada pada ketinggian $63 \mathrm{mdpl}$. Unsur megalitik terlihat pada jirat makam yang terbuat dari susunan batu-batu gunung berbentuk empat perseg panjang. Sementara jirat makam terdiri gundukan tanah yang dikelilingi susunan batu, jirat makam berbentuk persegi dengan jirat yang tampak ditingoikan. Berdampingan dengan makam dari istri Raja Latusitania (Syekh Abubaka Nasidik), hanya memiliki satu buah nisan yang berbentuk maupun jenisnya sama dengan nisam makam suaminya, sedangkan nisan yang satunya lagi, yakni nisan kaki, hanya terbuat dari batu menhir, berbentuk lonjong atau silindrik.

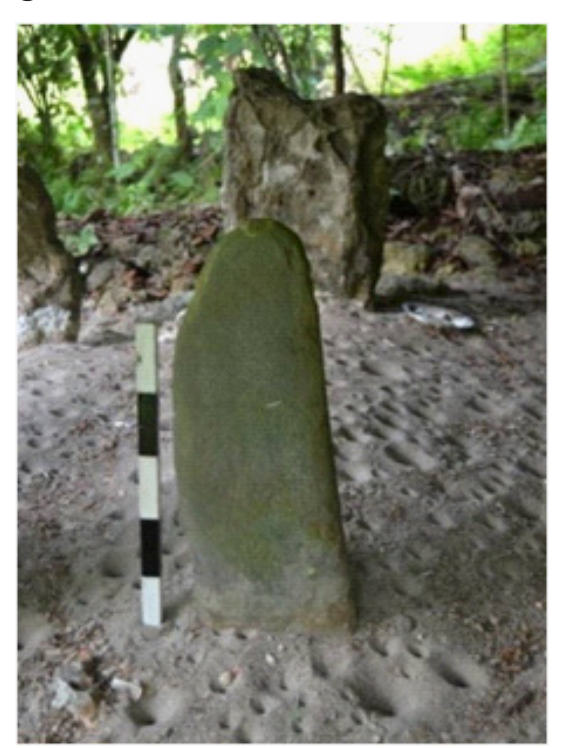

Gambar 3. Makam Muhammad Ali Mahdum

(Sumber: Dokumen Balar Ambon 2012)

Makam kedua adalah Makam Maulana Ali Mahdun Ibrahim (Raja Hitu kedua). Makam ini diperkuat dengan jirat berbentuk persegi panjang terdiri dari susunan batu sebagai penahan jirat berupa tanah yang ditinggikan. Ciri dari tradisi megalitik, yakni nisan batu. Nisan kepala tersusun dari batu karang yang berbentuk pipih, sedangkan nisan kaki tersusun dari batu andesit berbentuk pipih. Makam Maulana Ali Mahdum juga berdampingan dengan makam yang dipercaya sebagai makam istrinya. Kedua makam terdiri dari jirat gundukan tanah yang dikelilingi oleh susunan batu. Yang membedakan kedua makam ini adalah bentuk nisannya. Makam Maulana Ali Mahdum, nisannya terdiri dari batu menhir baik nisan kepala maupun nisan kaki. Nisan kepala merupakan nisan menhir berbentuk pipih terbuat dari sejenis batu atau karst gunung, sedangkan nisan kaki tersusun dari nisan menhir berbentuk silindrik. Sementara itu makam istrinya, nisan kaki dan kepala tersusun dari batuan gamping, merupakan nisan menhir berbentuk pipih, sedangkan nisan kaki, terbuat dari batuan gamping yang membentuk tipologi nisan tertentu, dari morfologinya menunjukkan tipe nisan Demak-Troloyo, namun kondisinya sudah sangat aus. Kedua makam ini terletak pada ketinggian $41 \mathrm{mdpl}$, yang masih areal dari negeri lama Amahitu. Makam ini terletak berdekatan dengan susunan batu yang dipercaya sebagai pondasi masjid Tujuh Pangkat, tepatnya di sebelah timur dari pondasi masjid.

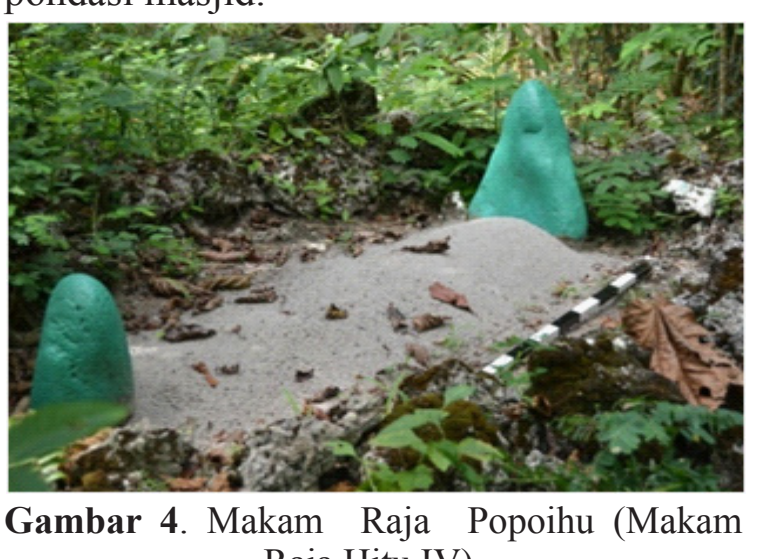

Gambar 4. Makam Raja

(Sumber: Dokumen Balar Ambon 2012)

Makam berikutnya, adalah makam Raja Popoihu (Raja Hitu Keempat), makam ini juga dikelilingi jirat yang tersusun dari batu karang yang berwarna hitam dan membentuk persegi panjang. Keletakan makam ini berada pada ketinggian $39 \mathrm{mdpl}$ Ditempat ini juga terdat dua makam. Makam yang lain dipercaya juga sebagai makam istrinya. Keletakan makam istrinya lebih rendah dibanding makam Raja Popoihu. Kedua makam tersusun dari jirat gundukan tanah yang dikelingi susunan batu sebagai penahan tanah. Kedua makam tersebut menggunakan nisan batu menhir berukuran kecil berbentuk silindrik, namun tampaknya diambil bentuk batu yang alami, tanpa proses pemangkasan batu.

$$
\text { Makam Raja Matiune (Raja Hitu }
$$

Kelima). Nisan makam ini terdiri dar nisan menhir, tersusun dari batuan beku. Keletakan makam ini berada pada ketinggian permukaan tanah $33 \mathrm{M}$ dpl. Pada masa raja Matiune, Kerajaan Hitu berhasil dikuasa Belanda dan masyarakat Hitu diperintahkan turun gunung dan menempati kampungkampung baru yang hingga sekarang ditempati yakni di pesisir.

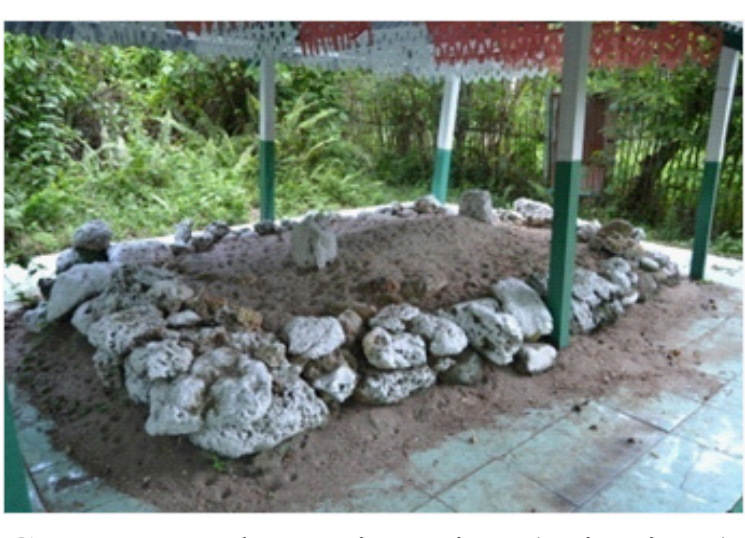

5ambar 5. Makam Raja Matiune (Raja Hitu V).

(Sumber: Dokumen Balar Ambon 2012)

Selain makam-makam di daerah perbukitan, dan terletak di luar pemukima desa, terdapat pula beberapa makam yang berada di wilayah pemukiman desa, salah satunya bahkan terdapat di kompleks pekuburan umum. Makam-makam tersebut. Makam-makam kuno, yang terdapat di wilayah pesisir pantai desa Hitu yang sekarang. Satu diantaranya terdapat $\mathrm{d}$ daerah ketinggian, namun masih dalam 
wilayah desa sekarang, yakni makam Baina Yasirullah Makam Bainayasirullah. Menurut cerita atau tradisi tutur setempat, pada abad 11, tokoh tersebut sudah ke Hitu, namun kembali ke Arab karena belum ada penduduk dipesisir Hitu. Pada waktu berikutnya setelah penduduk tinggal di pesisir, Baina Yasirullah datang kembali untuk menyiarkan Islam. Lokasi makam berada pada ketinggian 105 mdpl. Lokasi makam biasa disebut oleh penduduk dengan istilah Hatu Kursi atau Batu Kadera. Bentuk makam berupa gundukan tanah dengan nisan berupa nisan batu.

$$
\text { Sementara itu makam Raja }
$$

Maulana Bainamalamala, terletak di desa Hitumesseng (Desa Hitu yang baru di pesisir pantai), berada pada daerah pesisir pada 9 mdpl. Makam ini terletak di sebelah selatan desa Hitumessing. Selanjutnya makam Baina Alaurat (Alim Ulama Hitu), terletak di sebelah barat desa Hitu dan berada di kompleks pemakaman masyarakat, kurang lebih $15 \mathrm{~m}$ dari arah pantai. Kondisi makam sudah banyak diperbaharui, terutama cungkup yang menggunakan cungkup modern, terletak ditengah-tengah lokasi pekuburan umum di pinggir pantai dengan ketinggian $4 \mathrm{mdpl}$. Keseluruhan makam, juga memperlihatkan makam dengan bentuk nisan menhir, ada yang berbentuk persegi, ada pula yang berbentuk lonjong, tampak seperti batu alamiah tanpa ada proses pengerjaan.

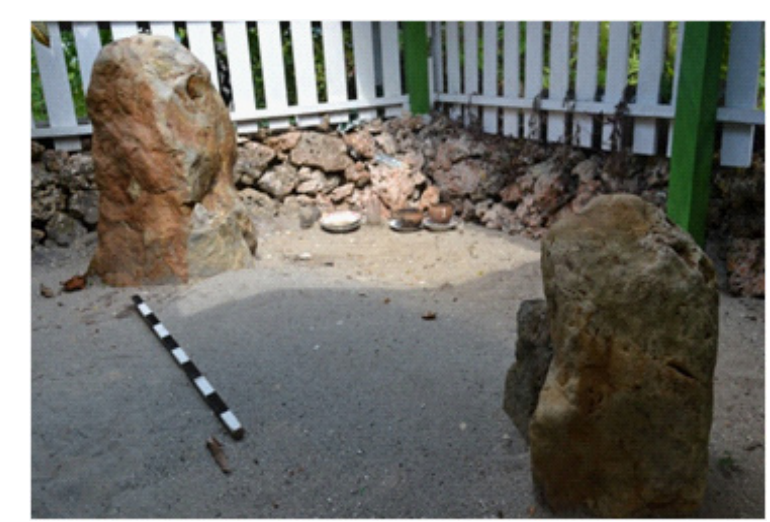

Gambar 6. Makam Baina Yasirullah yan dipercaya sebagai tokoh penyebar Islam pertam di wilayah Kerajaan Hitu.

(Sumber: Dokumen Balar Ambon 2012)
Jika melihat keletakan makam, tampak sebagian besar makam ditempatkan di daerah ketinggian. Khusus untuk raja-raja Hitu, semakin ke bawah, menunjukkan periode pemerintahan raja Hitu yang lebih muda, menunjukkan pula periode perkembangan permukiman dari pemukiman di atas bukit kemudian turun ke pantai pada masa pengaruh kolonial. Seperti yang dijelaskan sebelumnya, pada masa pemerintahan Raja Hitu Kelima yakni Raja Matiune, Kerajaan Hitu berhasil dikuasai Belanda dan masyarakat Hitu diperintahkan turun gunung dan menempati kampung-kampung baru yang hingoa sekarang ditempati yakn di pesir. Menang sut keletakan makni di pesisir. Menyangkut keletakan makan raja-raja Hitu dan penyiar Islam, tampakny dapat dijelaskan berdasarkan sudut pandang arkeologis. Ambary (1991), menjelaskan salah satu bukti aspek kesinambungan dalam tatacara pemakaman ialah penggunaan bukit atau gunung sebagai tempat pemakaman yang dianggap suci. Tradisi yang berasal dari masa pra Islam ini berlanjut bahkan sampa sekarang. Bila dipedataran areal makam ditinggikan, sebagaimana penempatan bangunan prasejarah atau candi ( Ambary, 1991: 13). Tampaknya ada dua penjelasan dalam soal ini, pertama keletakan makam raja-raja Hitu pada lokasi ketinggian, selain didasarkan pada pengaruh budaya megalitik, dimana lokasi ketinggian dianggap sebagai wilayah sakral atau suci juga di dasarkan pada faktor periode penghunian situs pada periode pemerintahan masing-masing raja, pada masa Raja Hitu pertama lebih tinggi dibandingkan periode pemerintahan raja berikutnya sesuai dengan periode penghunian lokasi pemukiman di daerah bukit yang kemudian menempati kampung-kampung di pesisir. Pertimbangan lokasi makam lebih didasarkan pada periode pemerintahan terhadap penguasa Islam pada masa itu. Kedua, pada makam Baina Yasirullah, meskipun wilayahnya dekat dengan pantai, namun berada pada lokasi yang lebih tinggi dibandingkan dengan makam raja-raja Hitu, dipengaruhi oleh kepercayaan yang merupakan unsur budaya megalitik bahwa lokasi ketinggian adalah daerah yang lebih sakral, dan penempatan lokasi makam tersebut juga sebagai penghormatan mengingat Baina Yasirullah adalah tokoh penyebar Islam yang pertama di wilayah Kerajaan Hitu.
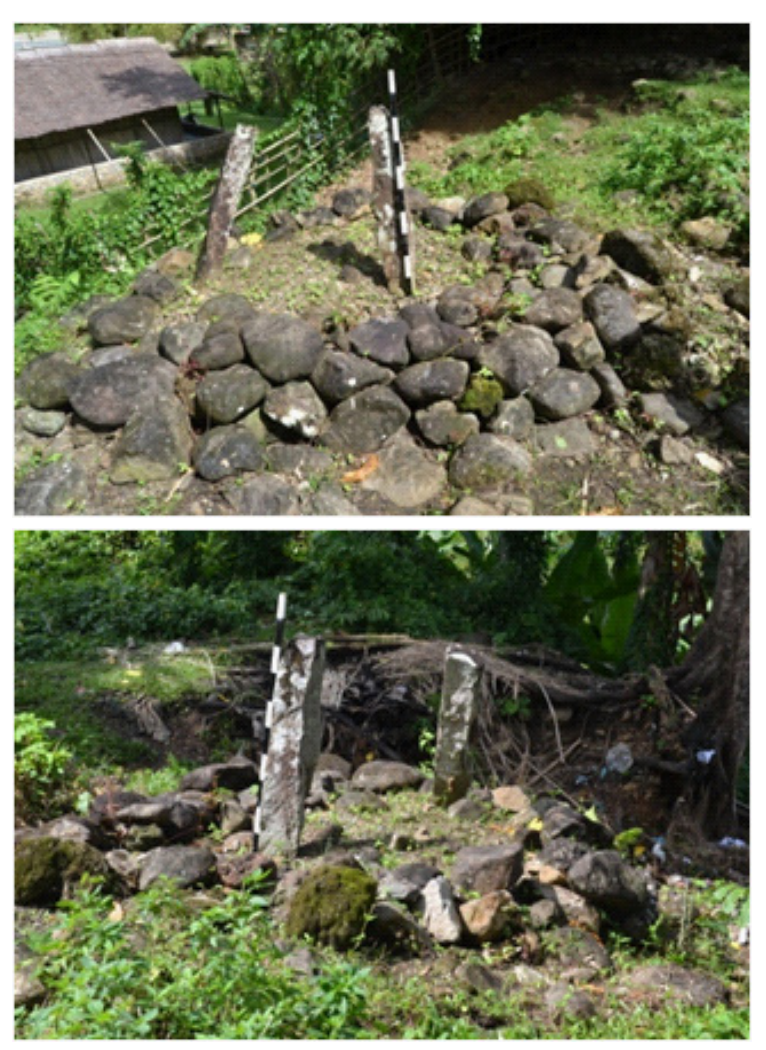

Gambar 7 dan 8. Makam Kuno Nisan Menhir di Kompleks Makam Kuno Raja-Raja Kaitetu. (Sumber: Dokumen Balar Ambon 2012)

Selanjutnya survei dan deskripsi ditujukan pada kompleks makam kuno RajaRaja Kaitetu. Di kompleks makam tersebut dimakamkan keluarga dari Soa Soulette dan Soa Nukuhaly, selain itu juga terdapat makam-makam dari keturunan marga Raja Kaitetu Lumaela. Sementara itu makam Raja Kaitetu Keenam, yakni Abdul Hamid Lumaela, makamnya berada di dekat Masjid Kuno Wapauwe, di sudut selatan masjid. Makam kuno pada umumnya tersusun dari bentuk sederhana, yakni jirat terbuka terdiri dari susunan batu dan nisan berbentuk menhir batu. Ini menunjukkan bahwa unsur budaya megalitik sangat kuat dalam tradisi makam raja-raja Kaitetu.

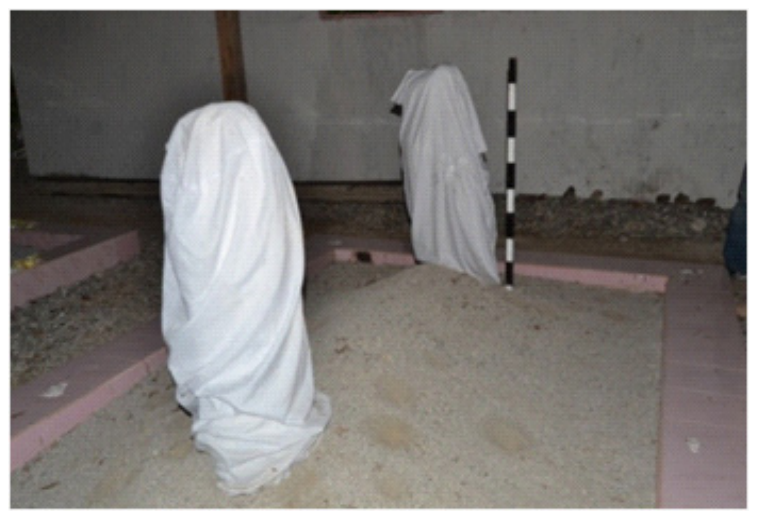

Gambar 9. Makam Raja Hasan Sulaeman di Negeri Hila

(Sumber: Dokumen Balar Ambon 2012)

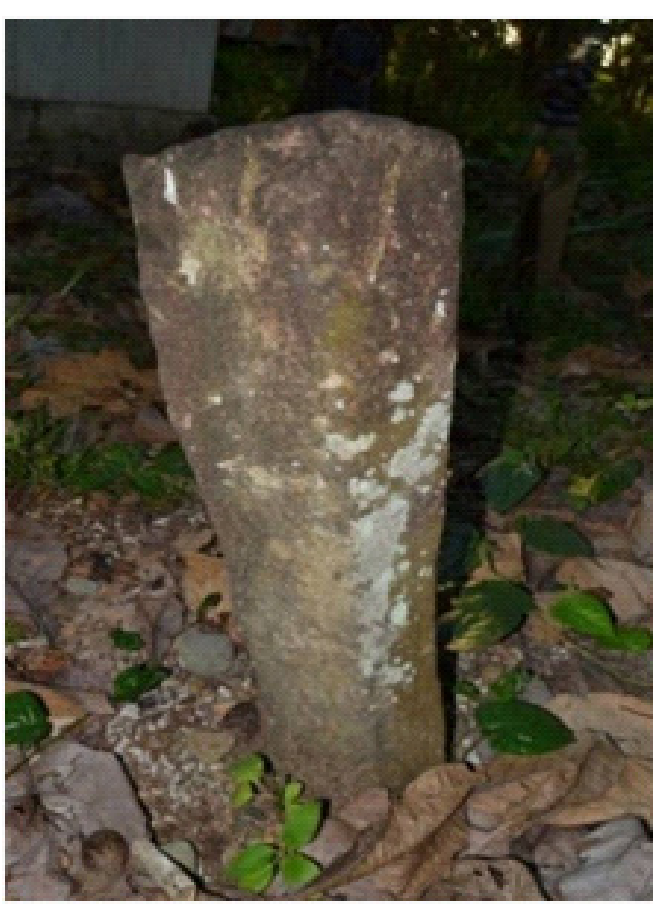

Gambar 10. Bentuk Nisan Makam Kerabat Raja Hasan Sulaeman di Negeri Hila.

(Sumber: Dokumen Balar Ambon 2012)

Survei dan deskripsi juga diarahkan ke Negeri Hila, yakni pada kompleks makam Hasan Sulaeman di Negeri Hila. Raja Hasan Sulaeman, adalah salah seorang penyiar Islam terkemuka di Negeri Hila. Dalam tradis tutur disebutkan bahwa Hasan Sulaeman adalah raja sekaligus Imam pertama di Negeri Hila, yang merupakan salah satu wilayah pemerintahan Kerajaan Hitu. Dalam catatan Valentin, Hasan Sulaeman adalah seorang 
Imam yang kaya raya dan baik hati (Dijk, 2009:51). Dengan demikian, Hasan Sulaeman adalah seorang yang memiliki strata sosia yang tinggi. Namun bentuk makam Hasan Sulaeman, sangat sederhana yakni jira terbuka yang bagian atasnya ditimbuni pasir, yang dikelilingi dinding semen yang rendah. Makam ini meskipun nisannya diselubungi kain putih dan dilarang untuk dibuka, dapa dipastikan bahwa makam tersebut terdiri dar nisan batu berbentuk menhir, yang serup dengan makam lainnya di sekitar makan Hasan Sulaeman. Makam ini ditempatkan terpisah dengan makam lainnya, yakni diberi cungkup berbentuk rumah yang dibangun pada masa sekarang. Di dalam rumah cungkup tersebut, selain makam Hasan Sulaeman, terdapat makam tokoh lain, yang menurut sumber adalah makam keluarga dan keturunannya, keseluruhan makam diselubungi kain putih pada nisannya, kecuali makam-makam keluarga dan keturunannya yang ditempatkan di luar bangunan cungkup

\section{Konversi Islam Dan Keberlanjutan Tradisi} Megalitik

Jauh sebelum pengaruh Islam hadir dan berkembang di bumi Nusantara ini, masyarakat Nusantara telah memiliki kepercayaan tentang ketuhanan. Paham ketuhanan atau kepercayaan terhadap sang pencipta telah tumbuh pada masyaraka Nusantara ini sejak masa yang sanga tua. Pemujaan terhadap kekuatan gaib diluar manusia, dimanifestasikan ole masyarakat lokal Nusantara, pada umumnya melalui medium pemujaan berupa batubatu besar. Tradisi megalithik di Nusantara telah menandai zamannya atas pengenalan, pengalaman dan membangun dialog bati dengan kekuatan diluar dirinya.

Berdasarkan data arkeologi di Kerajaan Hitu, yakni makam kuno dapa dihubungkan dengan sejarah islamisasi di wilayah tersebut. Sejak abad 14, penyebaran Islam mengalami puncaknya dan berkembang ke daerah lainnya di sekitar Hitu. Tinggalan- tnggalan arkeologis yang disebutkan diatas 16 , Islam sangat berkembang di wilayah Hitu. Kita lihat bagaimana dinamika Islam berlangsung di wilayah Kerajaan Hitu, tentu menunjukkan gambarannya yang hampir sama dengan Islam di wilayah Ternate. Selain Hitu dianggap setaraf dengan Ternate, menganut Islam pada rentang waktu yang relatif sama, apalagi kedua penguasanya baik Sultan Ternate maupun Raja Hitu, pernah sama-sama belajar Islam di Gresik (Putuhena, 2001:64-65; Burhanuddin, 2012:20). Perbedaan keduanya kemungkinan pada wilayah-wilayah kekuasaannya, diman wilayah kekusan Hitu lebih kecil, cil, skal kekuasaannya juga lebih kecil sehingga rentan sekali terhegemoni oleh kekuasaan yang lebih besar. Di Ternate, makam-makam Sultan dan keluarganya tampak lebih kaya ornament, baik nisan dan jiratnya, bahkan di beberapa tempat tipe nisan di Ternate berkembang ke wilayah lainnya. Nisan Ternate, kaya akan motif hias, berupa sulur-sulur dan flora yang sangat khas, yang oleh Ambary disebut motif Polinesia (Ambary 1998:73 ). Namun nyatanya di wilayah Kerajaan Hitu, sebaga salah satu pusat kekuasaan Islam, tipologi Nisan Ternate tidak berkembang, hal ini bisa jadi membuktikan, bahwa Hitu memang tidak pernah secara langsung menjadi wilayah ekspansi kekuasaan Ternate, sebagaimana banyak disebut oleh berbagai sumber tertulis (Putuhena, 2001: 65).

Di Hitu, tampaknya memiliki kekhasan sendiri dalam konversi Islam, meskipun Islam terus berkembang, namun budaya lokal yang cenderung megalithi sulit atau bahkan mungkin tak bisa dihilangkan. Kontinuitas unsur tradisi Pra Islam sangat tampak dari tipe nisan dan makam di wilayah Hitu, baik makam yang berada di pesisir maupun dengan makam di perbukitan. Fenomena ini menuru Mahmud (2001), menunjukkan intervensi budaya dari luar betatapun menjanjikannya tidak mentah-mentah diterima (Mahmud, 2001:79). Menurut ST Alisyahbana, setiap persentuhan dan interaksi suatu masyarakat dengan kebudayaan baru, selalu ada upaya kritis terhadap benda dan kejadian disekitarnya untuk memilih isi budayanya disekitarnya untuk memilih isi budayanya
(Koestoro, 1981:7). Pada kasus situs makam kuno di Hitu, kecenderungan unsur megalitis masih sangat dominan tampak pada bentuk nisan makam, yakni bentuk nisan yang yang menyerupai menhir berukuran sedang dan kecil, menunjukkan adanya perkembangan lokal dari fungsi menhir. Pada temuan makam kuno di negeri Hitu, baik di di perbukitan maupun di pesisir pantai yang dimukimi saat ini, tipe ini banyak ditemukan dalam bentuk persegi panjang,pipih dan bulat atau lonjong.

Kehadiran unsur Pra Islam dalam kriya masyarakat Nusantara menggambarkan bahwa unsur-unsur lokal masih merupakan afirmasi paling kuat dan paling energetik dalam menciptakan bentukbentuk budaya (Mahmud, 2001:74). Di wilayah kerajan (Mitu, Islam dengan bukibukti arkeologis bukti arkeologis dalam bentuk material makam Islam kuno menunjukkan bahwa masyarakat di satu pihak telah mendapat pengaruh budaya Islam, namun secara fisikal masih memperlihatkan dominasi lokal, yakni memperlihatkan kesinambungan dengan anasir budaya Pra Islam, yang oleh Ambary (1986; 1991) disebut sebagai permanensi etnologis. Permanensi bentuk makam dan nisan yang cenderung megalitis menurut Mahmud (2001:83) menunjukkan determinasi budaya lam Namun di wilayah Hitu, tampaknya perlu dilihat melalui perspektif yang berbeda. Determinasi Islam sangat kuat, mengingat banyak kegiatan ritual Islam terus berlangsung, namun masyarakat Hitu dan Maluku pada umumnya adalah masyarakat tradisional yang sangat kuat memegang adat. Bahkan mungkin dari aspek tertentu menunjukkan percampuran (sinkretisme) antara bentuk kepercayaan lama (penghormatan terhadap arwah leluhur yang berkembang pada masa megalitk) dengan religi Islam yang bersumber pada $\mathrm{Al}$
Quran dan Hadist. Oleh karena itu konversi slam dan kepercayaan adat yang tidak saling bertentangan menjadi aspek yang saling berintegrasi. Masyarakat Kerajaan Hitu, meskipun secara ideologis, merupakan masyarakat penganut Islam yang taat, namun bukti-bukti arkeologis menunjukkan karakter lokal yang cenderung megalithis juga masih sangat kuat. Dengan demikian permanensi etnologis yang ditemukan merupakan pembauran harmonis antar unsur megalitis dan budaya Islami.

Demikian pula tampaknya, karakter budaya Islami pada awal perkembangannya hingga sekarang di Hitu, cenderung sanga kental berbaur dengan kepercayaan lokal yang secara aktual merupakan kelanjutan dari tradisi megalithik. Tradisi nisan menhir, di kompleks makam kuno Islam, mengindikasikan adanya transisi dan transformasi budaya masa Pra-Islam ke zaman Islam dan bahkan trasformasi tersebut tidak menghilangkan unsur-unsur budaya lokal, sebaliknya justru saling berintegrasi. Sejak bermukim di puncak bukit (pedalaman), tampak sekali Islam telah hidup dan mulai berpengaruh terhadap budaya masyarakatnya. Zaman itu telah menanda zaman peralihan (transisi) masyarakat dari corak keagamaan lokal yang bersifat megalitis menuju kehidupan bercorak Islam. Dengan kata lain pada masa itu masyarakat telah mengawali persentuhannya dengan budaya Islam. Namun demikian, adanya tradisi nisan menhir di kompleks makam, menunjukkan bahwa budaya lokal dengan karakter megalitis masih sangat dominan.

Meskipun Islam sebagai sebua kekuatan transformatif dianggap telah memberdayakan masyarakat Nusantara untuk keluar dari paham-paham religi primitif (Mahmud, 2001:73), namun sebagai sebuah entitas kultur dan religi baru yang datang dari wilayah luar, ia tidak serta merta langsung diterima masyarakat Nusantara ini. Kenyataannya, pada awal perkembangannya, Islam hanya bisa diterima ketika mampu memberikan ruang bagi hidupnya pahampaham lama bersifat lokal. Itu pula 
tampaknya yang mendorong para wali di Jawa terutama Sunan Kalijaga, yang paling populer diantara para walisanga itu dalam penyebaran Islam, tetap mempertahankan bahkan meramu dan memadukan Islam dengan seni tradisi masyarakat Jawa yang berkembang pada masa itu, yakni wayang (lihat Ambary, 1991:9).

Di wilayah Kerajaan Hitu, pada awal pengaruh itu, Islam tak langsung diterima oleh masyarakat, hal ini disebabkan masyarakat menganut kepercayaan animisme, yakni kepercayaan terhadap nenek moyang (Sahusilawane, 1996:11). Hal yang sama juga sebagaimana dikutip Syaranamual dan Pattikayhatu (1997), yang menyatakan:

"sesungguhnya pada permulaan-

nya banyak betul daerah itu

yang memeluk Islam, namun

kemudian. Mereka hendak

tetap dalam kepercayaan yang

sama. Sangat sulit bagi mereka

membuang kebiasaan nenek

moyangnya. Mereka meng-

hendaki agama dapat sejala

hendaki agana dapat sejalan

dengan as

mereka"........(Syaranamual dan

Pattikayhatu, 1997:31)

Meskipun telah bersentuhan dengan Islam, namun kepercayaan lokal dengan medium benda-benda megalithik masih tetap bertahan dan terus hidup. Bahkan kemungkinan, pada masa dimana penduduk tinggal di perbukitan (pedalaman) transis Islam berjalan sangat lambat, mengingat daerah pedalaman masa itu lebih sulit terjangkau, dibandingkan dengan mas bermukim di pesisir pantai, seperti desa pesisir yang ditempati hingga sekarang ini. Pada masa bermukim di pedalaman kurangnya bukti material budaya islam menunjukkan kuatnya budaya lokal. Penjelasan tersebut pada dasarnya dapa memberikan gambaran tentang pengaruh budaya Islam yang sesungguhnya berlangsung akomodatif. Sementara itu, unsur lokal sangat dominan dan telah mengakar dalam tata laku masyarakat, mengingat telah berlangsung waktu yang panjang. Dengan demikian ha ini sangat berpengaruh, meskipun Islam terus berkembang, namun budaya lokal yang cenderung megalithis sulit atau bahkan mungkin tak bisa dihilangkan.

\section{PENUTUP}

Hasil penelitian arkeologi, membantu menemukan berbagai informasi yang tidak terangkat dalam studi sejarah, sehingga penelitian arkeologi merupakan domain yang penting untuk mengungkap sejarah budaya, terutama soal bagaimana perkembangan Islam dalam periodesasi tertentu yang kurang terangkat dalam studi sejarah, misalnya tentang dinamika Islam dan budaya lokal, yang dalam catatan sejarah masih dilupakan. Studi arkeologi melalui analisis serangkaian data artefaktual maupun situs membantu melengkapi informasi sejarah. Demikian pula dalam penelitian ini, diharapkan dapa melengkapi dan menambah bobot informas sejarah, yang beberapa diantaranya banyak bersumber dari tradisi tutur yang tidak bisa dilepaskan dari unsur bias dan subyektifitas narasumber.

Dari penelitian arkeologi ini, dapa disimpulkan bagaimana dinamika budaya masyaraat sejak awal konversi Islam hingga perkembangannya, ketika Islam telah menjad agama kerajaan, yang ditandai oleh para pemimpin wilayah setempat memeluk Islam. Kerajaan Hitu,sebagai wilayah pusat peradaban Islam di Maluku Tengah, tampak Islam menjadi agama kerajaan yang sanga akomodatif terhadap unsur-unsur lokal. Keberadaan makam-makam kuno raja yang sangat sederhana, dan cenderung melanjutkan tradisi leluhur, yakni tradisi nisan menhir sebagai kontinuitas tradisi megalitik, menunjukkan bahwa Islam sangat adaptif terhadap unur-unsur lokal. Upaya integras Islam dengan budaya leluhur yakni pemujaan terhadap leluhur, tampaknya merupakan kepercayaan yang sangat kuat pada masyarakat tradisional Kerajaan Hitu, sehingga penerimaan Islam, tanpa menegasikan tradisi-tradisidan kepercayaan terhadap religi lama, yakni kepercayaan terhadap arwah leluhur, yang hidup jauh sebelum Islam hadir di bumi Maluku. Hasil penelitian ini juga menggambarkan karakteristik Islam Maluku, yang pada beberapa aspek menunjukkan karakteristik yang umum ditemui di wilayahwilayah di Nusantara. Dengan demikian, membincangkan Islam di Maluku dalam sudut pandang arkeologi, merupakan domain yang penting dalam khasanah penelitian arkeologi Islam di Nusantara. Penelitian ini hanyalah salah satu aspek kecil dari beragam aspek kajian dari studi arkeologi Islam yang multiple aspek, karena masih banyak kajiankajian artefaktual yang masih harus diperluas dan diperdalam lagi jangkauan datanya, analisis dan berbagai kerangka konseptual dalam membahas sejarah budaya dalam episode Islamisasi dan perkembangannya di Maluku.

\section{DAFTAR PUSTAKA}

Ambary, Hasan Muarif., 1986. Unsur Tradisi Pra Islam Pada Sistem Pemakaman Islam di IV Jakarta: Depdikbud.

Ambary, Hasan Muarif., 1991. Makam-makam Kesultanan dan Parawali Penyebar Islam di Pulau Jawa. Dalam Aspek-aspek Arkeologi Indonesia No. I2. Jakarta: Pusat Penelitian Arkeologi Nasional.

Ambary, Hasan Muarif., 1998. Menemukan Peradaban Arkeologi dan Islam di Arkeologi Nasional. Jakarta: Logos Wacana Ilmu.

Ambary, Hasan Muarif, 2008. Beberapa Aspek Seni Budaya Islam Nusantara. Kumpulan Makah Pertemuan Ilmiah Arkeologi.

Bart, F. 1969. Introduction, in F. Bart (ed.) Ethnicgroups and boundariest : the social organisations of cultural
Bergen Universitets Forlaget. Burhanuddin, Jajat. 2012. Ulama dan Kekuasaan
Pergumulan Elit Muslim dalam Sejarah Indonesia. Jakarta: Mizan.

Dijk, Van Kees., 2009. Perubahan Kontur Masjid dalam Peter J.M Nas dan Martien de Kini Arsitektur Masa Lalu dalam Masa Gramedia Pustaka Utama.

Insoll, Timoty., 2004. Syncretism, Time, and Identity: Islamic Archaeology in West Africa. (In), Whitcomb, D. (ed.), Changing
Social Identity with the Spread of Islam. Social Identity with the Spread of Islam. Archaeological Per

Kaplan, David dan Albert A. Manners. 1999. Teori Budaya. Yogyakarta: Pustaka Pelajar.

Kartodirjo, Sartono. 1975. Sejarah Nasional Indonesia I. Jakarta: Departemen Pendidikan dan Kebudyaaan.

Koestoro, Lucas Pertanda. 1981. Akulturasi di Kraton Kesepuhan dan Mesjid Panjunan Cirebon. Berkala Arkeologi II. Yogyakarta: Balai Arkeologi Yogyakarta.

Mahmud, Irfan. 2001. Determinasi Budaya Islami di Wilayah Pinggiran Kekuasaan Bugis. Selatan dan Tenggara. Vol IV No 6 Juni. Makassar: Balai Arkeologi Makassar.

Sahusilawane, Florence. 1996. Laporan Hasil Penelitian Arkeologi Islam di Kecamatan Leihitu Kabupaten Maluku Tengah.
Ambon: Balai Arkeologi Ambon.

Soejono, RP, 1993. Jaman Prasejarah di Indonesia dalam Marwati Djoened Pusponegro dan Indonesia I. Jakarta: Balai Pustaka.

Sudewo, Eri, 1990 Pemujaan Kubur : Distorsi atau Retradisionalisasi dalam Proceeding Analisis Hasil Penelitian Arkeologi religi dalam Kaitannya dengan Kematian.
Jilid I. Jakarta. Pusat Arkeologi Nasional

Sukendar, Haris. 1983. "Peranan Menhir Dalam Masyarakat Prasejarah di Indonesia" dalam Satyawati Sulaeman et.al (ed.) Pusat Penelitian Arkeologi Nasional.

Syaranamual dan Pattikayhatu, John, 1997 Sejarah Kerajaan Iha. Departemnen Pendidikan dan kebudayaan. Balai Kjian 
Putuhena, Shaleh 2001 Proses Perluasan Agama Islam di Maluku Utara. Dalam M.J. Abdulrahman, et.al. Ternate: Bandar Jalur Sutera, Ternate: LinTas (Lembaga Informasi dan Transformasi Sosial).

Wiyana, Budi, 2005 Bahan Nisan Makam : Studi Kasus Makam di Mentok, Pulau Bangka. Pertemuan Ilmiah Arkeologi (PIA IX). Ikatan Ahli Arkeologi Indonesia. Yogyakarta.

Wiyana, Budi, 2008 Dari Menhir ke Nisan : Suatu Dinamika Budaya. Kumpulan Makah Pertemuan Ilmiah Arkeologi. Kediri, 2328 Juli 2002. Jakarta. IAAI 